\title{
Phosphate Cements Based on Calcined Dolomite: Influence of Calcination Temperature and Silica Addition
}

\author{
Cristina Andreea Vijan, Alina Badanoiu *, Georgeta Voicu and Adrian Ionut Nicoara \\ Department of Science and Engineering of Oxide Materials and Nanomaterials, Faculty of Applied Chemistry and \\ Materials Science, University Politehnica of Bucharest, 1-7 Gheorghe Polizu Street, 011061 Bucharest, Romania; \\ cris_deea_vajan@yahoo.com (C.A.V.); georgeta.voicu@upb.ro (G.V.); adrian.nicoara@upb.ro (A.I.N.) \\ * Correspondence: alina.badanoiu@upb.ro
}

check for updates

Citation: Vijan, C.A.; Badanoiu, A.; Voicu, G.; Nicoara, A.I. Phosphate Cements Based on Calcined Dolomite: Influence of Calcination Temperature and Silica Addition. Materials 2021, 14, 3838. https://doi.org/10.3390/ ma14143838

Academic Editor: Rossana Bellopede

Received: 7 June 2021

Accepted: 6 July 2021

Published: 9 July 2021

Publisher's Note: MDPI stays neutral with regard to jurisdictional claims in published maps and institutional affiliations.
Abstract: The aim of this study is to assess the possibility of obtaining phosphate cements based on dolomite calcined at various temperatures with/without quartz sand addition. A lower calcination temperature of dolomite $\left(1200{ }^{\circ} \mathrm{C}\right)$ determines a high increase in the system temperature when calcined dolomite is mixed with $\mathrm{KH}_{2} \mathrm{PO}_{4}(\mathrm{MKP})$ solution and also a rapid expansion of the paste. The increase in calcination temperature up to $1400{ }^{\circ} \mathrm{C}$ reduces the oxides reactivity; however, for lower dosages of MKP, the expansion phenomenon is still recorded. The increase in MKP dosage increases the compressive strength due to the formation of K-struvite. The mixing of dolomite with sand, followed by thermal treatment at $1200{ }^{\circ} \mathrm{C}$, modifies its composition and reactivity; the compressive strength of phosphate cements obtained by mixing this solid precursor with MKP increases up to 28 days of curing. We assessed the nature of hydrates formed in the phosphate systems studied by X-ray diffraction in order to explain the hardening processes and the mechanical properties of these systems. The microstructure and elemental composition of hardened cement pastes were assessed by scanning electronic microscopy with energy-dispersive spectroscopy. The phosphate cements based on calcined magnesite or dolomite were used to immobilize an industrial hazardous waste with high chromium content. The partial substitution of calcined magnesite/dolomite with this waste determines an important decrease in compressive strengths. Nevertheless, the leaching tests confirm an adequate immobilization of chromium in some of the matrices studied (for a waste dosage corresponding to $0.5 \mathrm{wt} \% \mathrm{Cr}$ ).

Keywords: phosphate cements; calcined dolomite; quartz sand; calcined magnesite; temperature; K-struvite; industrial waste; chromium

\section{Introduction}

Magnesium phosphate cement (MPC) hardens due to an acid-base reaction between magnesia $(\mathrm{MgO})$ and phosphate acid or a phosphate salt solution [1-4]. The usual source of magnesium oxide is magnesite (magnesium carbonate), which is thermally treated at increasing temperatures to obtain caustic calcined magnesite/magnesia (CCM), dead burned magnesite/magnesia (DBM), and fused magnesia (FM). CCM has numerous applications such as hydrometallurgy, steel industry, ceramic and cement manufacture, fertilizers, water treatment, etc. $[5,6]$. DBM and FM are mainly used in the manufacturing process of refractory materials [5], but DBM is also a key ingredient in MPC manufacture.

In the 2014 "Report on critical raw materials for EU", magnesite was identified as a critical raw material [5]. Taking into account this aspect, it is important to find alternative sources of raw materials for the manufacture of MPC.

Dolomite is a sedimentary rock containing calcium and magnesium carbonates $[7,8]$. Dolomite is an important material in various industries such as the pharmaceutical industry, metallurgy, the production of paper, inorganic binders, concrete, fertilizer, refractory bricks, water treatment, absorption of heavy metals, etc. [8-10]. 
The calcination of dolomite is used to transform this mineral into magnesium and calcium oxides. Depending on the experimental conditions, i.e., chemical composition of dolomite, presence and amount of impurities, grain size distribution, decomposition temperature and atmosphere (air, carbon dioxide, nitrogen etc.), the thermal decomposition of dolomite in $\mathrm{MgO}$ and $\mathrm{CaO}$ can proceed in one or several steps (endothermic processes) [8,11-13].

Yu et al. [14] studied the possibility of using dolomite as raw material to produce magnesium phosphate cement. According to these authors, mixing fine dolomite with coarse quartz sand and thermal treatment at relatively low temperatures $\left(1100-1250{ }^{\circ} \mathrm{C}\right)$ substantially reduces the amount of free lime, and the $\mathrm{MgO}$ obtained has an adequate reactivity vs. phosphate salt $\left(\mathrm{NH}_{4} \mathrm{H}_{2} \mathrm{PO}_{4}\right)$. The compressive strengths of phosphate cements pastes prepared with this type of calcined dolomite can reach $22 \mathrm{MPa}$ after $3 \mathrm{~h}$ of hardening and $63 \mathrm{MPa}$ after 7 days, with sufficient soundness [14].

MPCs can be used for the immobilization of various types of wastes with heavy metals content such as $\mathrm{Ni}, \mathrm{Pb}, \mathrm{Cr}, \mathrm{Cd}$, etc. [15-19]. Heavy metals are toxic and can cause serious health problems. Chromium (especially Cr (VI)) has an important toxic effect; it can produce skin irritation and ulcerations as well as liver and kidney deficiency and, if inhaled, it increases lung cancer risk [20].

Deng et al. [16] studied the influence of $\mathrm{Cr}^{3+}$ (brought in the system by $\mathrm{Cr}\left(\mathrm{NO}_{3}\right)_{3} \cdot 9 \mathrm{H}_{2} \mathrm{O}$ ) on the compressive strength, microstructure, as well as leaching toxicity of solidified forms into MPCs based on calcined magnesite and $\mathrm{KH}_{2} \mathrm{PO}_{4}$. According to these authors, the presence of $\mathrm{Cr}^{3+}$ changed the system's $\mathrm{pH}$ and affected the morphology of hydration products; however, the MPCs leaching toxicity was less than the one assessed for other matrices i.e., geopolymer, calcium aluminum cement, and alkali-activated slag binders.

Therefore, we assessed in this paper the possibility of producing phosphate cements by replacing calcined magnesite with dolomite thermally treated at various temperatures, with/without quartz sand addition. We also evaluated the efficiency of magnesium phosphate cements (MPC) based on calcined magnesite and magnesium and calcium phosphate cements (MCPC) based on calcined dolomite in order to immobilize an industrial waste with high chromium content. To the best of our knowledge, the immobilization of chromium in phosphate cements based on calcined dolomite has been first reported in this paper.

\section{Materials and Methods}

The precursors used in this study were as follows:

- Calcined magnesite (M), industrial product (Tremag, Tulcea, Romania), obtained by the calcination of magnesite at $1500{ }^{\circ} \mathrm{C}$; the residue on sieve 90 microns mesh was $7.93 \%$.

- Calcined dolomites, obtained by thermal treatment of natural dolomite (Rodbungrup, Bucharest, Romania) at $1200{ }^{\circ} \mathrm{C}\left(\mathrm{D}_{12}\right)$ and $1400{ }^{\circ} \mathrm{C}\left(\mathrm{D}_{14}\right)$ for $3 \mathrm{~h}$. The natural dolomite had a content of $47 \% \mathrm{CaCO}_{3}$ and $37.5 \% \mathrm{MgCO}_{3}$ and a residue on 90 microns mesh of $24.83 \%$. After the thermal treatment, the calcined dolomites were ground up to a fineness corresponding to total passing through a 90 microns sieve.

- $\quad$ Calcined mixture of dolomite and quartz sand $\left(\mathrm{D}_{12 \mathrm{~S}}\right)$; the sand (Societe Nouvelle du Litoral, Leucate, France) had a fineness corresponding to total passing through a 200 microns sieve. The dolomite to quartz sand ratio was 1.5, and the thermal treatment was performed at $1200{ }^{\circ} \mathrm{C}$ for $1 \mathrm{~h}$, based on the results reported by Yu et.al. [14]. The rate of heating was $10^{\circ} \mathrm{C} /$ minute, and the cooling was performed in the oven.

- $\quad$ Potassium dihydrogen phosphate $\left(\mathrm{KH}_{2} \mathrm{PO}_{4}-\mathrm{MKP}\right)$, chemical reagent Sigma-Aldrich (Darmstadt, Germany).

- $\quad$ Setting retarder-borax (B)—chemical reagent Sigma-Aldrich (Darmstadt, Germany).

- Industrial waste with high chromium content $(2.71 \%)$ in the form of $\mathrm{CaCrO}_{4} \cdot 2 \mathrm{H}_{2} \mathrm{O}$ [21]; $\mathrm{CaCO}_{3}, \mathrm{Mg}(\mathrm{OH})_{2}$, and $\mathrm{Ca}(\mathrm{OH})_{2}$ were also detected by X-ray diffraction in this waste. 
The waste also contains $\mathrm{Si}, \mathrm{Al}, \mathrm{Fe}$, and $\mathrm{S}$ as well as very small amounts of $\mathrm{As}, \mathrm{Ba}, \mathrm{Cu}$, $\mathrm{Hg}, \mathrm{Mn}, \mathrm{V}, \mathrm{W}, \mathrm{Zn}$ and $\mathrm{Zr}$ [21]. in Table 1.

The compositions of the magnesium (and calcium) phosphate cements are presented

Table 1. Compositions of phosphate cements based on calcined magnesite (M) and calcined dolomite (D) with/without chromium waste.

\begin{tabular}{|c|c|c|c|c|c|c|c|c|c|}
\hline Sample & $\begin{array}{c}\text { Calcined } \\
\text { Magnesite } \\
\text { (M) } \\
\text { wt } \%\end{array}$ & $\begin{array}{c}\text { Calcined } \\
\text { Dolomite } \\
\text { (D) } \\
\text { wt } \%\end{array}$ & $\begin{array}{c}\mathrm{KH}_{2} \mathrm{PO}_{4} \\
\text { (MKP) } \\
\text { wt } \%\end{array}$ & $\begin{array}{c}\text { Borax * } \\
\text { (B) } \\
\text { wt } \%\end{array}$ & $\begin{array}{l}\text { Sand } \\
\text { wt \% }\end{array}$ & $\begin{array}{l}\text { Cr Waste } \\
* * \\
\% \text { wt } \%\end{array}$ & $\begin{array}{c}\text { M or D to } \\
\text { MKPRatio } \\
(w t)\end{array}$ & $\begin{array}{l}\text { Water to } \\
\text { Solid } \\
\text { Ratio } \\
\text { (wt) }\end{array}$ & $\begin{array}{c}\text { Calcination } \\
\text { Temperature } \\
\left({ }^{\circ} \mathrm{C}\right)\end{array}$ \\
\hline M_MKP_4_B3.3 & 80 & - & 20 & 3.3 & - & - & 4 & 0.2 & 1500 \\
\hline M_MKP_4_B3.3_Cr 1 & 50.4 & - & 12.6 & 3.3 & - & 37 & 4 & 0.35 & 1500 \\
\hline M_MKP_4_B3.3_Cr_0.5 & 64.8 & - & 16.2 & 3.3 & - & 19 & 4 & 0.35 & 1500 \\
\hline $\mathrm{D}_{12} \mathrm{~W}$ & - & 100 & - & - & - & - & - & 0.8 & 1200 \\
\hline $\mathrm{D}_{12} \mathrm{MKP} 4$ & - & 80 & 20 & - & - & - & 4 & 0.67 & 1200 \\
\hline D12_MKP_B3.3_4 & - & 80 & 20 & 3.3 & - & - & 4 & 0.67 & 1200 \\
\hline D 12 _MKP_2.5 & - & 71.43 & 28.57 & - & - & - & 2.5 & 0.55 & 1200 \\
\hline $\mathrm{D}_{12 \mathrm{~S}} \mathrm{MKP}_{2}$ & - & 40.2 & 33 & - & 26.8 & - & 2 & 0.2 & 1200 \\
\hline $\mathrm{D}_{14}$ MKP_4 & - & 80 & 20 & - & - & - & 4 & 0.3 & 1400 \\
\hline $\mathrm{D}_{14}$ MKP_2 & - & 67 & 33 & & - & - & 2 & 0.2 & 1400 \\
\hline $\mathrm{D}_{14} \mathrm{MKP} 2 \mathrm{Cr} 1$ & _- & 42 & 21 & _- & _- & 37 & 2 & 0.35 & 1400 \\
\hline $\mathrm{D}_{14}$ MKP_2_Cr0.5 & - & 54 & 27 & - & - & 19 & 2 & 0.35 & 1400 \\
\hline D ${ }_{12 S}$ _MKP_2_Cr0.5 & - & 32.4 & 27 & - & 21.6 & 19 & 2 & 0.2 & 1200 \\
\hline
\end{tabular}

${ }^{*}$ Borax dosage was calculated with reference to calcined magnesite or calcined dolomite. ${ }^{* *} \mathrm{Cr}$ waste was dosed to bring in the system $0.5 \mathrm{wt} \% \mathrm{Cr}$ and $1 \mathrm{wt} \% \mathrm{Cr}$; $\mathrm{Cr}$ waste substitutes the oxide + phosphate salt mixture.

The specimens were obtained by the mixing of solid component (calcined magnesite or calcined dolomite) with potassium dihydrogen phosphate, water, and in some cases borax; the resulting paste was poured in rectangular molds $(15 \mathrm{~mm} \times 15 \mathrm{~mm} \times 60 \mathrm{~mm}$ width $\times$ heigh $\times$ length). The curing of specimens was performed in the mold the first $24 \mathrm{~h}$ and then, after demolding, in air at $20 \pm 2{ }^{\circ} \mathrm{C}$.

The reactive $\mathrm{CaO}$ and $\mathrm{MgO}$ content (available for the reaction with water) of calcined dolomite was determined according to the method presented in the standard SR EN 4592 [22]. The available (unbound) $\mathrm{CaO}$ and $\mathrm{MgO}$ and corresponding hydroxides are dissolved in a sucrose solution and titrated with hydrochloric acid.

A Shimadzu XRD 6000 (Shimadzu, Kyoto, Japan), $\mathrm{CuK} \alpha(\lambda=1.5406 \AA$ ), $2 \theta$ ranging between 10 and 60 , a 0.02 step size, and a $2 \mathrm{deg}$./min scan speed was used for $\mathrm{X}$ ray diffraction analyses.

The microstructure of pastes was assessed by Scanning Electron Microscopy (SEM) using an FEI Inspect F50 (Thermo Fisher-former FEI, Eindhoven, Nederland) electronic microscope equipped with a Schottky emission electron beam with a resolution of $1.2 \mathrm{~nm}$ at $30 \mathrm{kV}$ and $3 \mathrm{~nm}$ at $1 \mathrm{kV}$ (BSE). In this analysis, the freshly fractured samples were visualized in a vacuum mode using a $30 \mathrm{kV}$ acceleration voltage and spot 3.5 .

A differential thermal analyzer Shimadzu DTG-TA 51H (Shimadzu, Kyoto, Japan) was used for complex thermal analysis (DTA-TG); the analyses were performed in air, with a heating rate of $10^{\circ} \mathrm{C} /$ minute, in the temperature range $20-1000^{\circ} \mathrm{C}$.

Prismatic specimens $(15 \mathrm{~mm} \times 15 \mathrm{~mm} \times 60 \mathrm{~mm}$ - width $\times$ heigh $\times$ length $)$, cured for 1 up to 28 days in air at $20 \pm 2{ }^{\circ} \mathrm{C}$, were employed for the assessment of compressive strength using a Matest testing machine (Matest, Treviolo, Italy). For the calculation of average compressive strength, a minimum of 6 compressive strength values were considered. The outliers $( \pm 10 \%)$ were not considered in calculation.

The chromium leaching test was performed according to the method presented in standard SR EN 12457-4: 2003 [23]. The MPC and MCPC specimens, hardened in air at $20 \pm 2{ }^{\circ} \mathrm{C}$ for 28 days, were triturated and sieved; the particles smaller than $10 \mathrm{~mm}$ were mixed with water (water to solid ratio was 10). The resulting suspension was stirred for $24 \mathrm{~h}$ at a rate of $10 \mathrm{rpm}$ by means of an orbital shaker (Heidolph Instrument Gmbh\&Co.KG, Schwabach, Germany); next, the suspension was filtered, and the leachate was mixed with 
nitric acid to achieve a $\mathrm{pH}$ lower than 2. An atomic absorption spectrometer (Analytik, Jena, Germany) was used to assess the heavy metals concentration in the leachate.

\section{Results}

The X-ray diffraction patterns of natural dolomite presented in Figure 1 confirm the presence of dolomite $\left(\mathrm{CaMg}\left(\mathrm{CO}_{3}\right)_{2}\right)$ along with a small amount of calcite $\left(\mathrm{CaCO}_{3}\right)$.

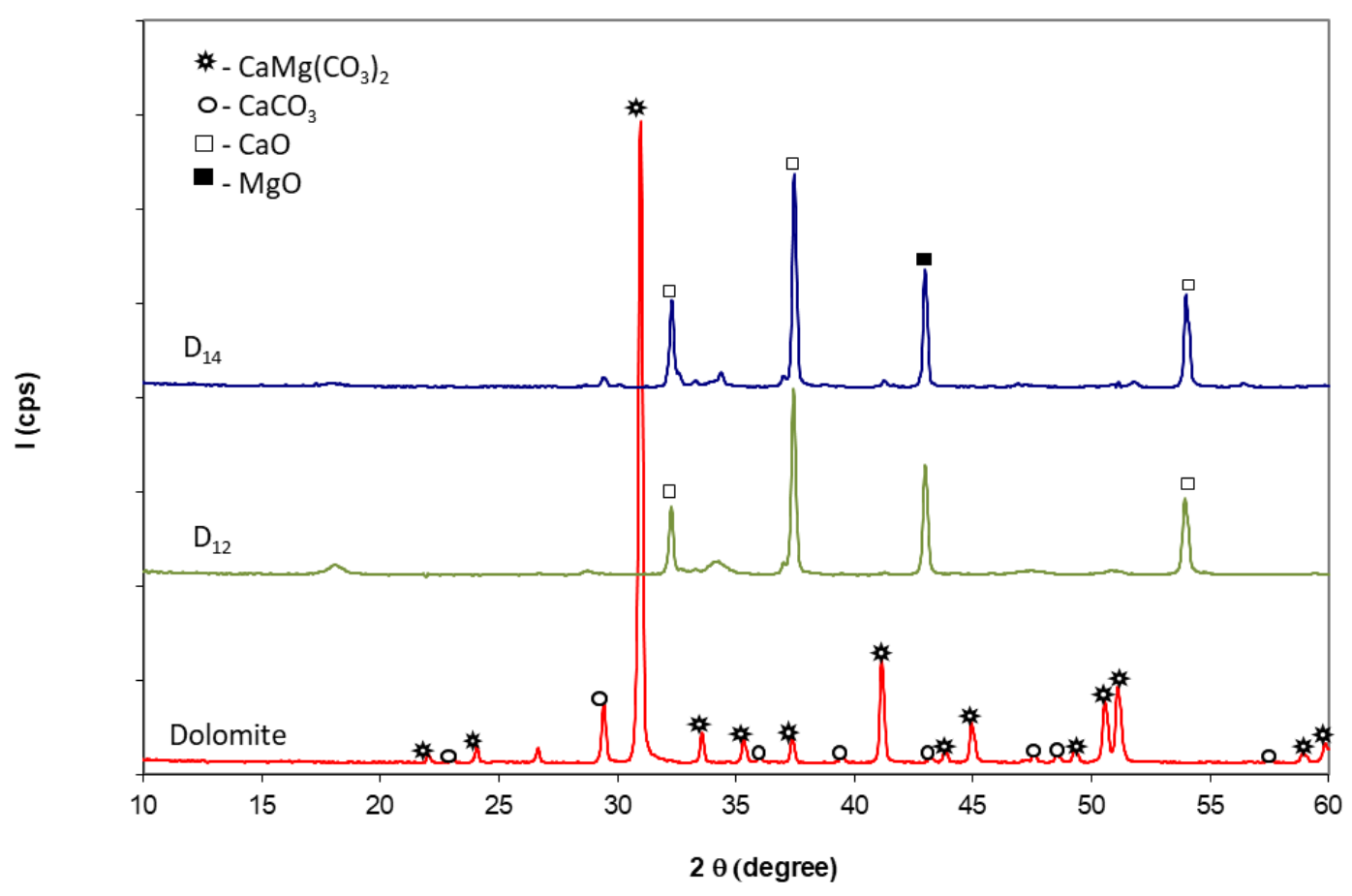

Figure 1. XRD patterns of dolomite and dolomite calcined at $1200{ }^{\circ} \mathrm{C}\left(\mathrm{D}_{12}\right)$ and $1400{ }^{\circ} \mathrm{C}\left(\mathrm{D}_{14}\right)$ for $3 \mathrm{~h}$.

The complex thermal analysis of dolomite (Figure 2) shows on the DTA curve an endothermic process with a shoulder at approximately $650{ }^{\circ} \mathrm{C}$ and maximum at $800{ }^{\circ} \mathrm{C}$ with a corresponding weight loss of $46.35 \%$ (assessed on TG curve). This process, which ends at $850^{\circ} \mathrm{C}$, can be attributed to the decarbonation of the magnesium carbonate and the calcium carbonate with $\mathrm{CaO}$ and $\mathrm{MgO}$ formation [8,11-13].

In correlation with previous results, the thermal treatment of dolomite at $1200{ }^{\circ} \mathrm{C}$ and $1400{ }^{\circ} \mathrm{C}$ leads to the transformation of calcium magnesium carbonate (083-1530) and calcium carbonate (072-1652) into magnesium oxide (004-0829) and calcium oxide (0821690) (Figure 1). There are no significant differences between the XRD patterns of dolomite thermally treated at these two temperatures.

The mixing of dolomite with quartz sand and thermal treatment at $1200{ }^{\circ} \mathrm{C}$ for $1 \mathrm{~h}$ determines, as expected, the formation of calcium and/or magnesium silicates (see Figure 3). The XRD patterns presented in Figure 3 also show the presence of $\mathrm{SiO}_{2}$ along with $\mathrm{MgO}$. The intensities of XRD peaks of $\mathrm{CaO}$ are much smaller (as compared with those assessed on $\mathrm{D}_{12}$ and $\mathrm{D}_{14} \mathrm{XRD}$ patterns-Figure 1) due to its partial consumption in the reaction with $\mathrm{SiO}_{2}$. 


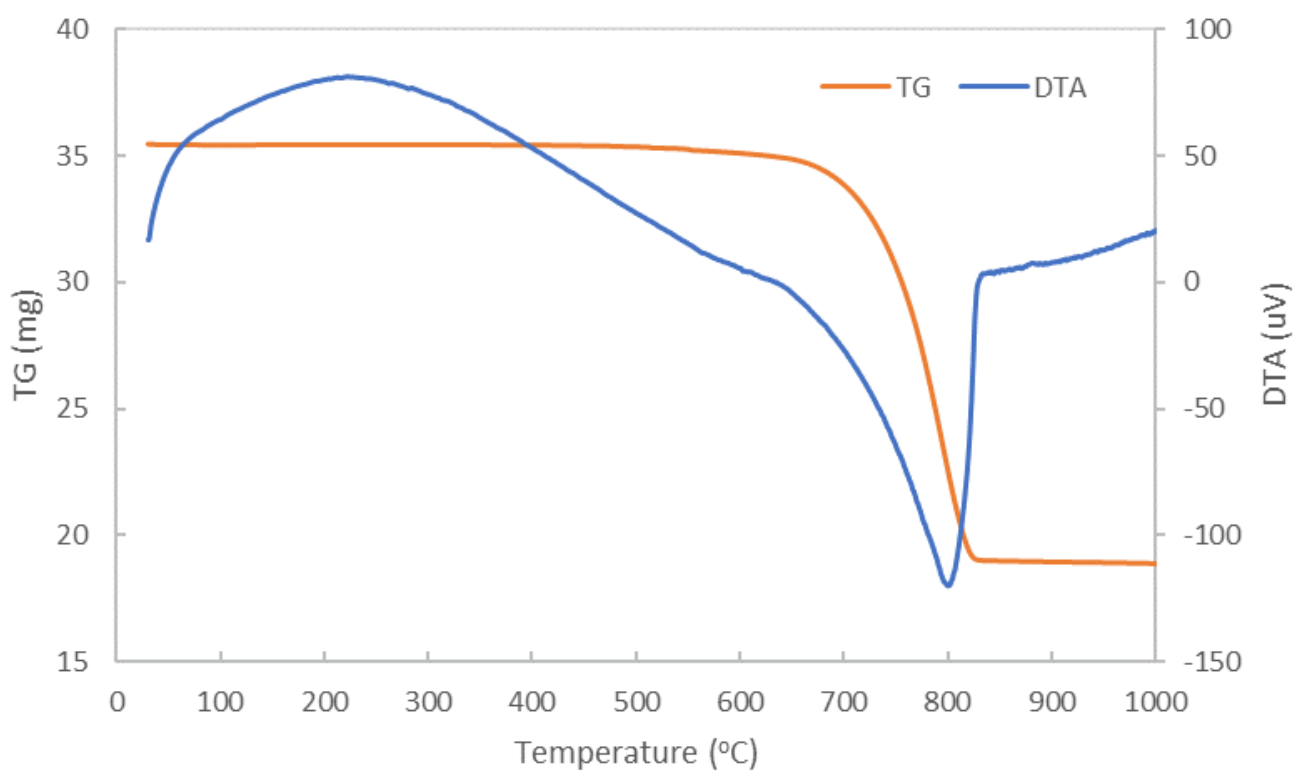

Figure 2. TG-DTA curves of dolomite.

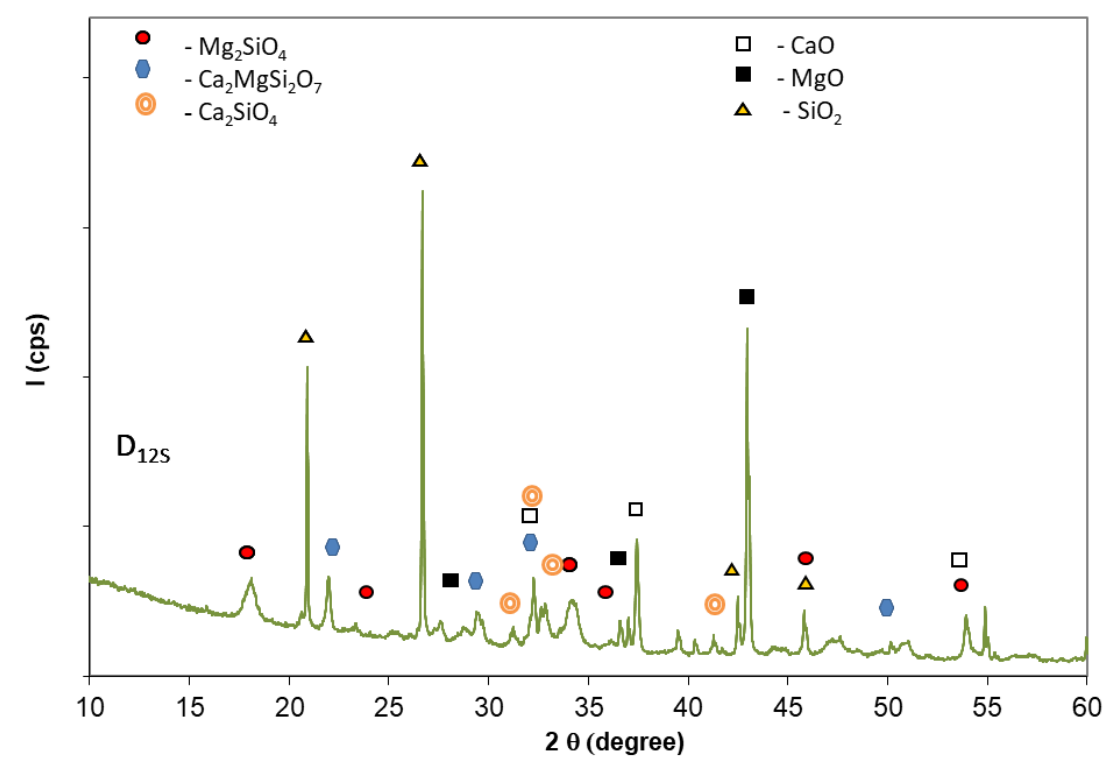

Figure 3. XRD patterns of dolomite with sand calcined at $1200^{\circ} \mathrm{C}\left(\mathrm{D}_{12 \mathrm{~S}}\right)$ for $1 \mathrm{~h}$.

The amount of reactive calcium and magnesium oxides assessed by the method presented in SR EN 459-2 [22] in the dolomite thermally treated for $3 \mathrm{~h}$ at $1200{ }^{\circ} \mathrm{C}$ was $54.13 \%$, and for the dolomite calcined at $1400{ }^{\circ} \mathrm{C}$, it was $22 \%$. The decrease of oxides reactivity when the thermal temperature increases is due, as in the case of thermal treatment of limestone, to the increase of oxides' crystals sizes correlated with the decrease of porosity, when the material is thermally treated at a higher temperature [24-27].

The mixing with water $(\mathrm{W})$ or $\mathrm{KH}_{2} \mathrm{PO}_{4}$ solution (MKP) determines, for the specimens based on the dolomite calcined at $1200{ }^{\circ} \mathrm{C}$, an intense and rapid heat release (Table 2), due to the hydration of $\mathrm{MgO}$ and $\mathrm{CaO}$ (in the case of $\mathrm{D}_{12} \mathrm{~W}$ ) and to the reaction with the MKP (in the case of $D_{12} \_M K P \_4$ and $\left.D_{12} \_M K P \_2.5\right)$. It has been noticed that a decrease of MKP content determines a slower heat release corresponding to the exothermic processes specific for the setting and hardening of these phosphate systems i.e., the maximum temperature assessed on pastes is reached after a longer time (see $D_{12}$ MKP_4 as compared to $\mathrm{D}_{12 \_} \mathrm{MKP} \_2.5$ - Table 2). 
Table 2. Maximum temperature $\left(\mathrm{T}_{\max }\right)$ and corresponding time $\left(\mathrm{t}_{\max }\right)$ for the studied binders.

\begin{tabular}{|c|c|c|c|}
\hline Sample & $\mathrm{T}_{\max } *\left({ }^{\circ} \mathrm{C}\right)$ & $t_{\max } * *(\min )$ & Obs. \\
\hline $\mathrm{D}_{12 \_W}$ & 98 & 4 & Expansion \\
\hline $\mathrm{D}_{12 \_} \mathrm{MKP} \_4$ & 90 & 26 & Expansion \\
\hline D $12 \_M K P \_2.5$ & 90 & 10 & Expansion \\
\hline
\end{tabular}

Figure 4 shows the $\mathrm{XRD}$ patterns of sample $\mathrm{D}_{12} \_\mathrm{W}$ after 3 days of hardening. It can be observed the presence of $\mathrm{Ca}(\mathrm{OH})_{2}$ (084-1276) resulting from the hydration of $\mathrm{CaO}$ and the presence of $\mathrm{Mg}(\mathrm{OH})_{2}$ (084-2163) resulting from the hydration of $\mathrm{MgO}$-both exothermic processes that explain the significant temperature increase; the presence of $\mathrm{MgO}$ peaks on the XRD patterns confirms the smaller reactivity vs. water of this oxide as compared to $\mathrm{CaO}[24,27,28]$, which correlates with the thermal treatment temperature and plateau.

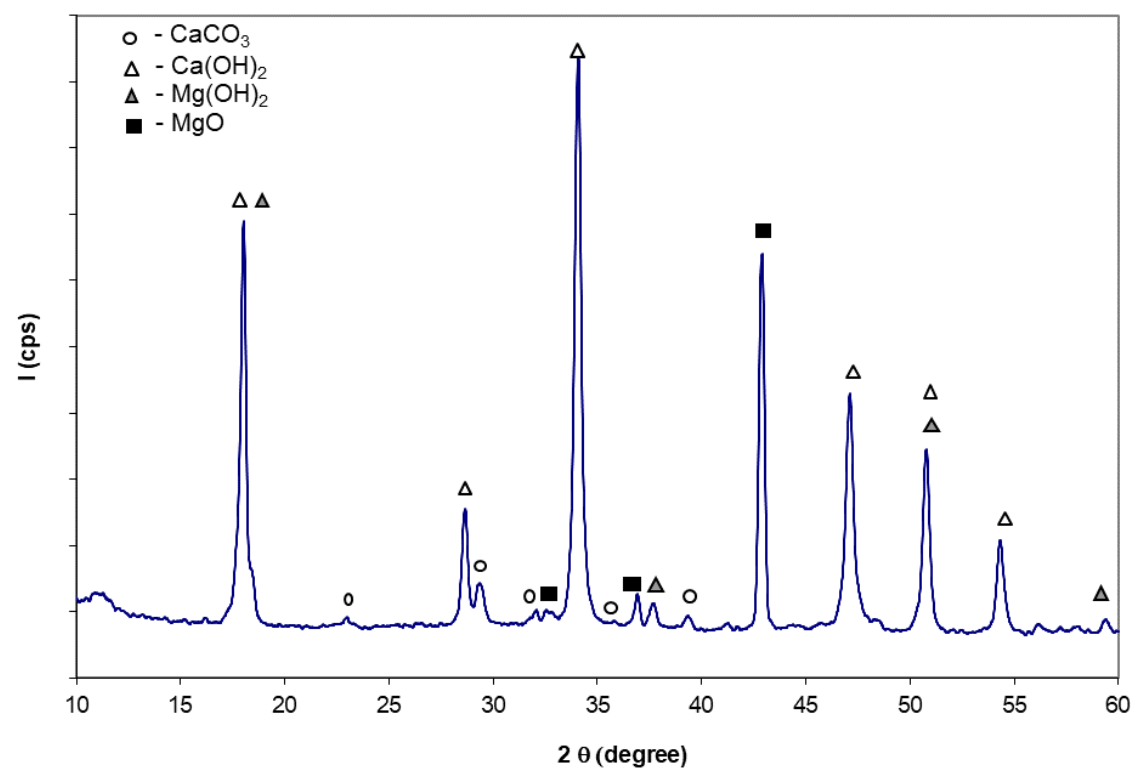

Figure 4. XRD patterns of paste obtained by mixing of water with dolomite calcined at $1200{ }^{\circ} \mathrm{C} / 3 \mathrm{~h}\left(\mathrm{D}_{12} \_\mathrm{W}\right)$.

On the XRD patterns of cements based on dolomite with/without borax and MKP (Figure 5a) can be noticed the presence of calcium and magnesium hydroxides as well as the presence of hydroxyapatite (HAp) - which resulted in the reaction of calcium with phosphate, which was brought into the system by the potassium dihydrogen phosphate (MKP). The formation of HAp is also facilitated by the basicity of this system (the addition of MKP to the calcined dolomite + water mixture shifts the $\mathrm{pH}$ value at 8-9). 


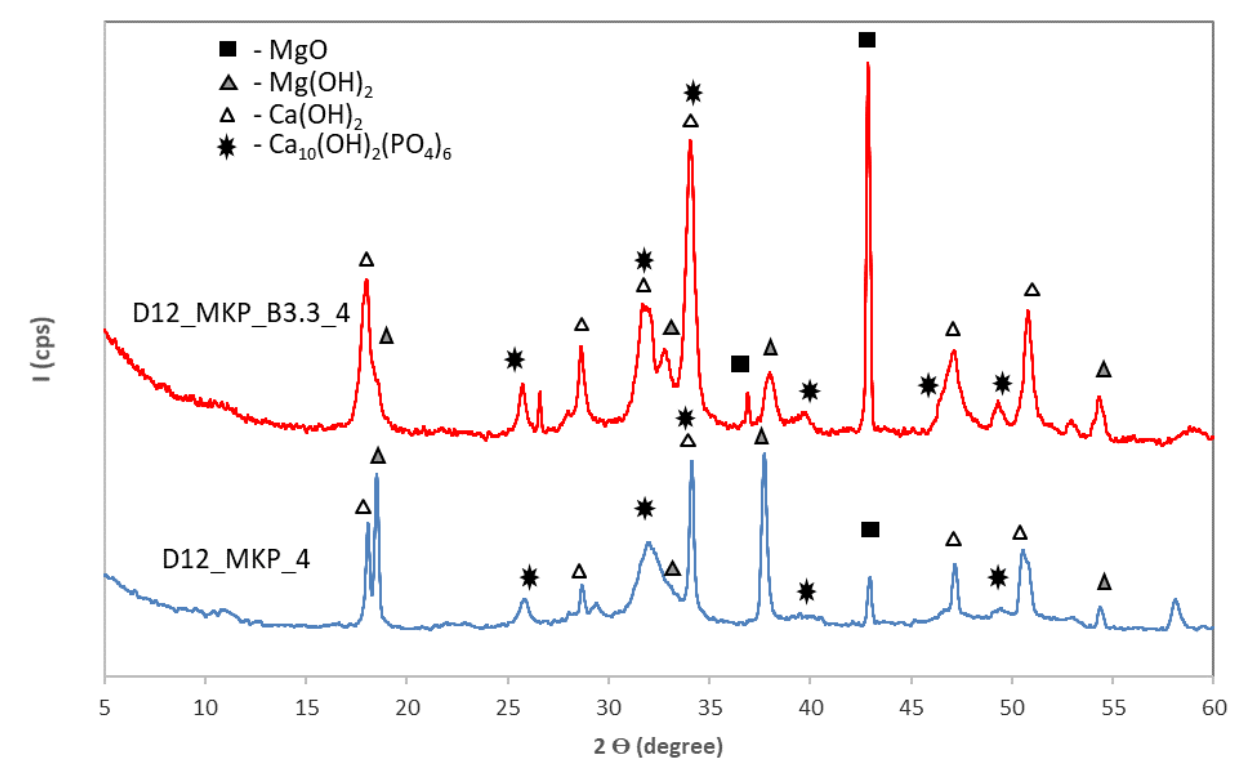

(a)

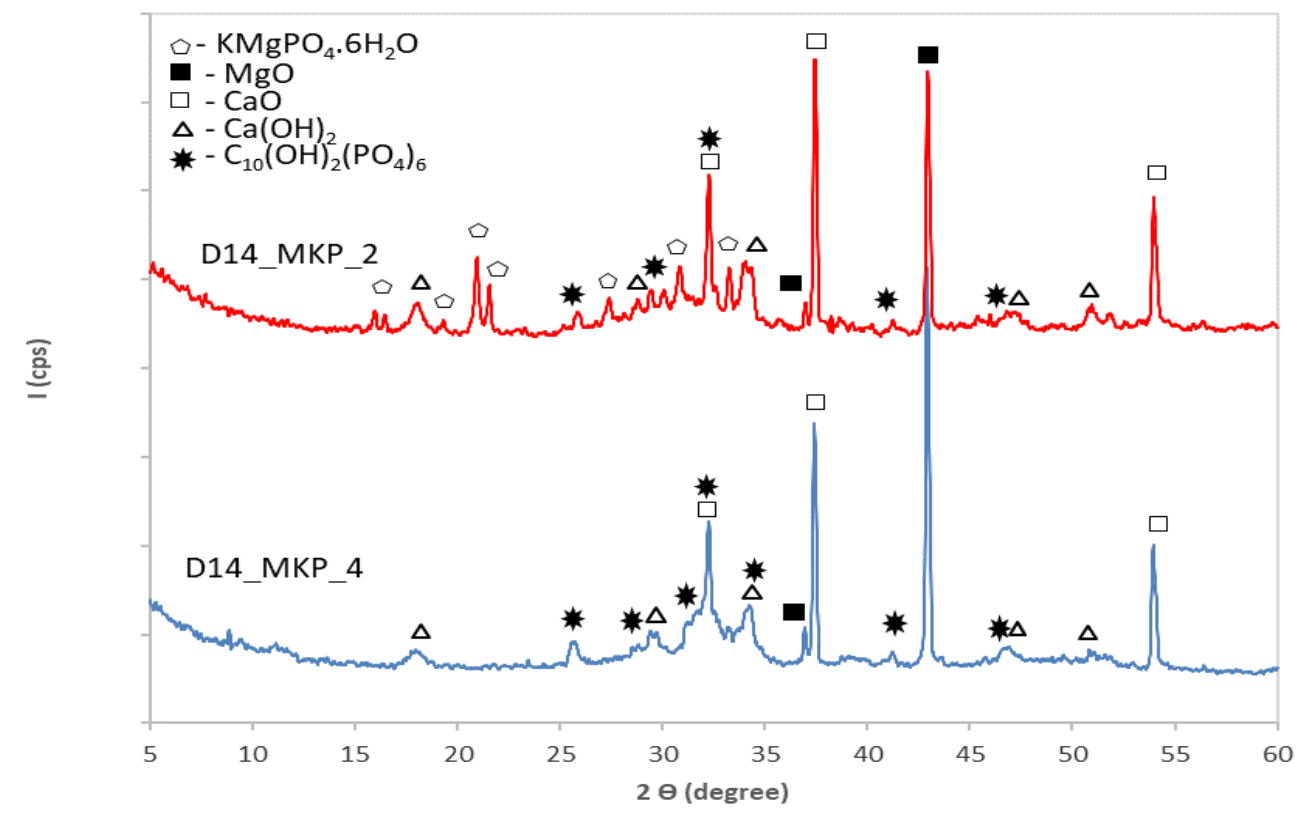

(b)

Figure 5. XRD patterns of the paste obtained by mixing water with potassium dihydrogen phosphate (with/without borax) and dolomite calcined for $3 \mathrm{~h}$ at (a) $1200{ }^{\circ} \mathrm{C}$; (b) $1400{ }^{\circ} \mathrm{C}$.

Due to the high reactivity vs. water or MKP solution of dolomite calcinated at $1200{ }^{\circ} \mathrm{C}$, phosphate cements based on dolomite calcined at $1400{ }^{\circ} \mathrm{C}$ were also obtained.

Figure $5 \mathrm{~b}$ shows the XRD patterns of phosphate cements based on dolomite calcined at $1400{ }^{\circ} \mathrm{C}$ prepared with different dosages of potassium dihydrogen phosphate (MKP). In the case of the specimens with a higher dosage of $\mathrm{KH}_{2} \mathrm{PO}_{4}$ (D $\mathrm{D}_{14}$ MKP_2) along with XRD peaks specific for magnesium oxide (004-0829), calcium oxide (082-1690), calcium hydroxide (084-1276) and HAp (084-1998) (which are also present on XRD patterns of $\left.\mathrm{D}_{14 \_} \mathrm{MKP} \_4\right)$ appear also XRD peaks specific for K-struvite $\left(\mathrm{KMgPO}_{4} \cdot 6 \mathrm{H}_{2} \mathrm{O}\right)(020-0685)$. Due to the higher reactivity of $\mathrm{CaO}$ as compared to $\mathrm{MgO}[24,27,28]$, HAp is the first reaction product formed in this system; if there are still available phosphate groups in the solution, K-struvite is formed by their reaction with magnesium. The presence of K-struvite contributes to the increase of mechanical strength $[29,30]$. 
These results are in correlation with the values of compressive strengths, which are presented in Table 3. The higher compressive strengths were assessed for the MPC based on calcined magnesite (M_MKP_4_B3.3) in which the main reaction product is K-struvite [30]. The specimens based on dolomite calcined at $1400{ }^{\circ} \mathrm{C}$ have recordable strengths only when the $\mathrm{MgO} / \mathrm{KH}_{2} \mathrm{PO}_{4}$ ratio is 2, i.e., when $\mathrm{K}$-struvite is detected in the hardened paste.

Table 3. Compressive strengths versus time. Influence of $\mathrm{Cr}$ waste presence.

\begin{tabular}{ccccc}
\hline \multirow{2}{*}{ Specimens } & \multicolumn{4}{c}{ Compressive Strength (MPa) } \\
\cline { 2 - 5 } & 1 Day & 3 Days & 7 Days & 28 Days \\
\hline M_MKP_4_B3.3 & 16.87 & 21.62 & 26.5 & 27.1 \\
M_MKP_4_B3.3_Cr0.5 & 0.6 & 1 & 1.15 & 1.5 \\
M_MKP_4_B3.3_Cr1 & 0 & 0 & 0 & 0 \\
D 14_MKP_4 & 0 & 0 & 0 & 0 \\
D14_MKP_2 & 7.1 & 10.8 & 12.2 & 0 \\
D14_MKP_2_Cr0.5 & 1.5 & 1.7 & 2 & 0 \\
D14_MKP_2_Cr1 & 0 & 0 & 0 & 0 \\
D12S_MKP_2 & 2.8 & 6.3 & 7.2 & 9.2 \\
D12S_MKP_2_Cr0.5 & 0 & 3.5 & 5.4 & 5.4 \\
\hline
\end{tabular}

In order to assess the influence of chromium waste on the composition of hardened phosphate cements, pastes with various amounts of waste were prepared (Table 1). The XRD patterns of the pastes based on calcined magnesite $(\mathrm{M})$ and dolomite calcined at $1400{ }^{\circ} \mathrm{C}\left(\mathrm{D}_{14}\right)$ with a dosage of chromium waste corresponding to $0.5 \mathrm{wt} \% \mathrm{Cr}$ are presented in Figure 6.

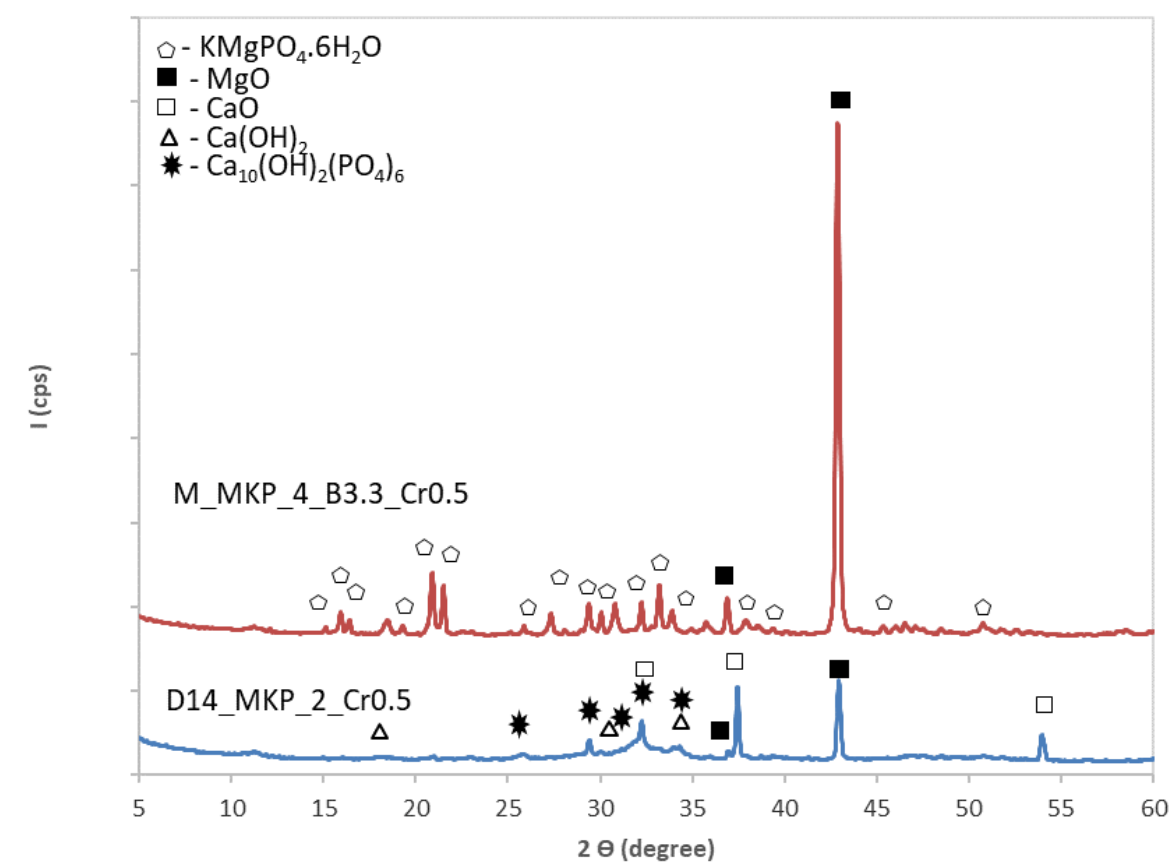

Figure 6. XRD patterns of the specimens based on calcined magnesite or dolomite calcined at $1400{ }^{\circ} \mathrm{C}$ with chromium waste corresponding to $0.5 \mathrm{wt} \% \mathrm{Cr}$.

For the paste based on magnesite (M_MKP_4_B3.3_Cr0.5), one can assess through this method the presence of $\mathrm{MgO}$ and $\mathrm{K}$-struvite $\left(\mathrm{KMgPO}_{4} \cdot 6 \mathrm{H}_{2} \mathrm{O}\right)$. The substitution of calcined magnesite with chromium waste determines an important decrease of the compressive strengths (Table 3), which could be due both to the smaller amount of K-struvite formed in the system (chromium waste substitute calcined magnesite and MKP) as well as the increase 
of water dosage (from 0.2 to 0.35 -see Table 1 ) necessary to improve the workability of fresh paste.

For the specimen based on calcined dolomite $\left(D_{14}\right)$, the presence of chromium waste seems to inhibit the K-struvite formation (see also Figure $5 b$ ). This explains the decrease of compressive strengths values as compared with those recorded for specimen $\mathrm{D}_{14}$ MKP_2, with the increase of $\mathrm{Cr}$ content (see Table 3). However, after 7 days of hardening, the compressive strength of specimens based on $\mathrm{D}_{14}\left(\mathrm{D}_{14 \_}\right.$MKP_2 and $\mathrm{D}_{14 \_} \mathrm{MKP} \_2$ 2Cr0.5) dramatically decrease, which is most probably due to a delayed hydration of free $\mathrm{CaO}$ and $\mathrm{MgO}$.

Therefore, in order to reduce the free lime content and to obtain magnesium oxide with an adequate reactivity, while keeping the same thermal treatment temperature of $1200{ }^{\circ} \mathrm{C}$, a mixture of dolomite and quartz sand was thermally treated at this temperature for $1 \mathrm{~h}$, based on the method proposed by Yu et al. [14].

The XRD pattens of the phosphate cement based on dolomite + sand calcined at $1200{ }^{\circ} \mathrm{C}-\mathrm{D}_{12 \mathrm{~S}}$ (Figure 7) show the presence of hydrates i.e., K-struvite and $\mathrm{Ca}(\mathrm{OH})_{2}$ along with $\mathrm{MgO}, \mathrm{SiO}_{2}$, and $\mathrm{Mg}_{2} \mathrm{SiO}_{4}$ assessed in $\mathrm{D}_{12 \mathrm{~S}}$ (see Figure 3). The presence of chromium waste does not change the nature of the reaction products (hydrates) assessed by this method (Figure 7).

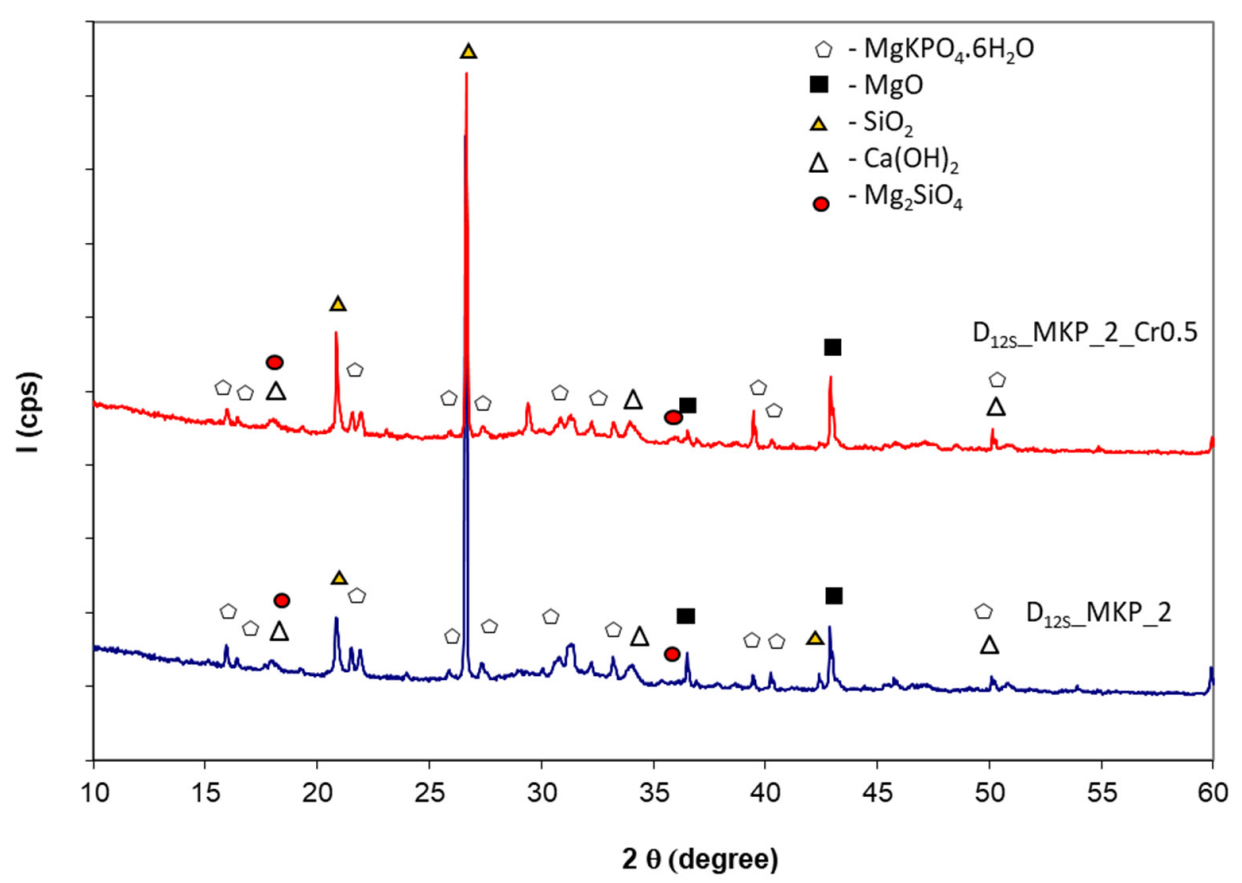

Figure 7. XRD patterns of the pastes obtained by mixing potassium dihydrogen phosphate and dolomite + sand calcined for $1 \mathrm{~h}$ at $1200^{\circ} \mathrm{C}$, with/without chromium waste.

In correlation with the above presented data, the compressive strengths of phosphate cements based on dolomite + sand calcined at $1200{ }^{\circ} \mathrm{C}\left(\mathrm{D}_{12}\right.$ __MKP_2 $)$ are lower in comparison to the ones assessed for the phosphate cement based on magnesite (M_MKP_B3.3_4); however, these values steadily increase up to 28 days (Table 3 ). This compressive strength evolution can be related to the formation of K-struvite (assessed by XRD) and to the presence of sand grains, which act as aggregates (Figure 8).

Figure 9 presents the SEM images and elemental compositions assessed by EDX on various areas of $D_{125} \_M K P \_2$ cement paste. As can be seen from Figure $9 a$, in area 1 , the atomic ratio of K:Mg:P is 13.25:13.14:14.14 confirming the presence of K-struvite in these specimens; the elemental compositions in area 3 (Figure 9a) and area 1 (Figure 9b) show the presence of $\mathrm{Ca}$ together with $\mathrm{Mg}, \mathrm{K}$, and $\mathrm{P}$, which suggest a complex composition of these hydrates [14]. 

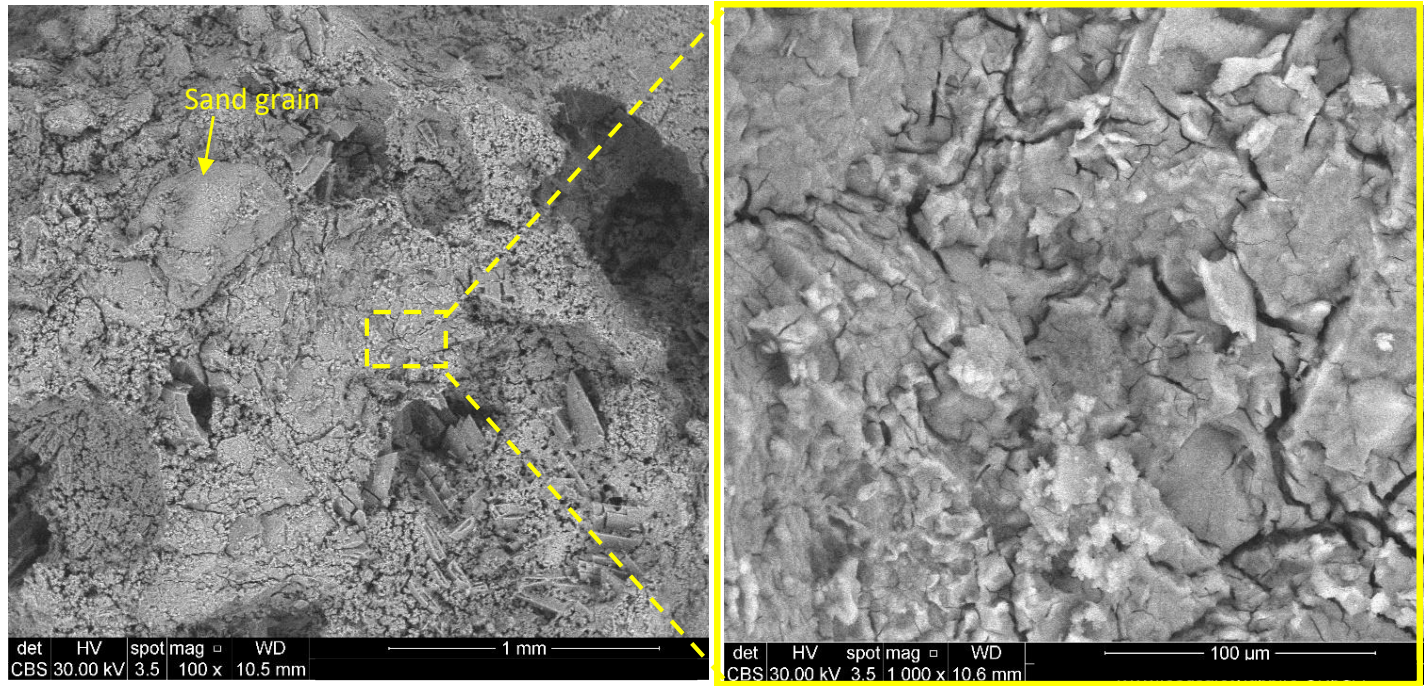

Figure 8. BSE images of $\mathrm{D}_{12 S} \_\mathrm{MKP} \_2$.

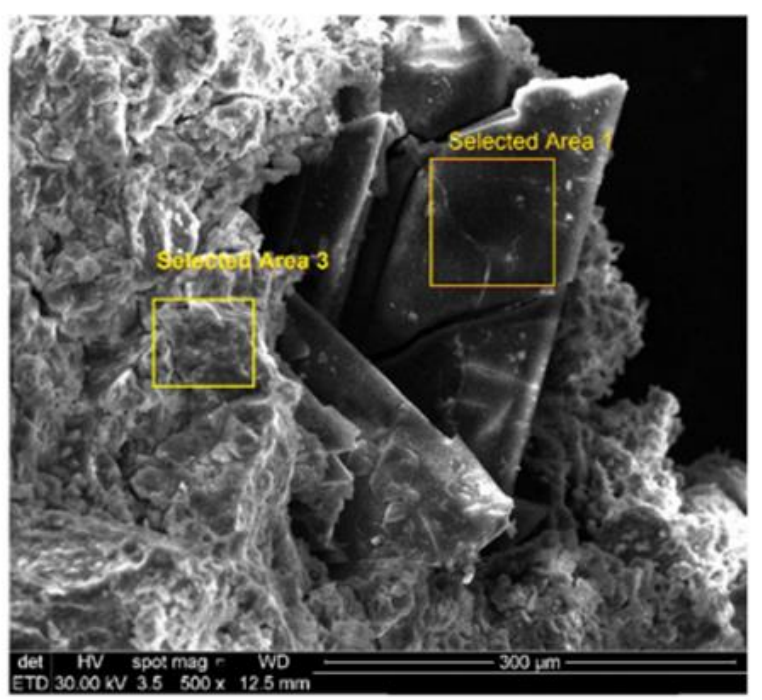

\begin{tabular}{|c|c|c|}
\hline Element & $\begin{array}{c}\text { Area 1 } \\
\text { (atomic \%) }\end{array}$ & $\begin{array}{c}\text { Area 3 } \\
\text { (atomic \%) }\end{array}$ \\
\hline $\mathrm{Mg}$ & 13.14 & 4.29 \\
\hline $\mathrm{Si}$ & 0.45 & 0.18 \\
\hline $\mathrm{P}$ & 14.14 & 9.18 \\
\hline $\mathrm{K}$ & 13.25 & 8.78 \\
\hline $\mathrm{Ca}$ & 0.43 & 5.3 \\
\hline $\mathrm{C}$ & 3.76 & 4.71 \\
\hline $\mathrm{O}$ & 54.83 & 67.56 \\
\hline
\end{tabular}

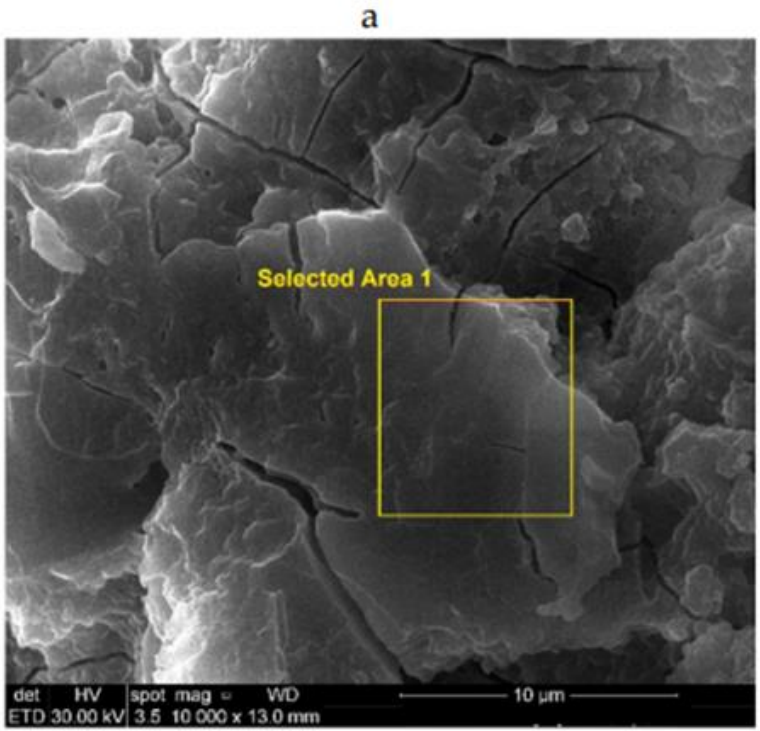

\begin{tabular}{|c|c|}
\hline Element & $\begin{array}{c}\text { Area 1 } \\
\text { (atomic \%) }\end{array}$ \\
\hline $\mathrm{Mg}$ & 7.49 \\
\hline $\mathrm{Si}$ & 1.05 \\
\hline $\mathrm{P}$ & 13.10 \\
\hline $\mathrm{K}$ & 12.83 \\
\hline $\mathrm{Ca}$ & 5.34 \\
\hline $\mathrm{O}$ & 60.19 \\
\hline
\end{tabular}

b

Figure 9. SEM images and EDX analyses of $D_{12 S} \_M K P \_2$ cement paste at different magnifications: $(\mathbf{a}) \times 500 ;(\mathbf{b}) \times 10,000$. 
For the cement paste based on $\mathrm{D}_{12 \mathrm{~S}}$, the presence of chromium waste (in a dosage corresponding to $0.5 \mathrm{wt} \% \mathrm{Cr}$ ) determines a reduction of compressive strengths in comparison to the cement without $\mathrm{Cr}\left(\mathrm{D}_{12}\right.$ __ $\left.M K P \_2\right)$; however, these values increase up to 28 days (Table 3). The decrease of compressive strengths can be explained by the lower amount of $\mathrm{MgO}$ (sand partially substitutes the dolomite) available in this system for the formation of K-struvite.

For a better understanding of the correlation between the morphology/composition and properties of $\mathrm{D}_{12 \mathrm{~S}}$ MKP_2_Cr0.5, SEM and EDX analyses were performed on this specimen (Figure 10). As it can be noticed, the sand grains are embedded in a continuous matrix (Figure 10a) in which are present plate-like and prismatic crystals intermixed with agglomerates of small grains (Figure 10b). The coherence of this matrix seems to be much lower in these specimens in comparison to the one without $\mathrm{Cr}$ (Figure 9), which can explain the lower mechanical strength values.

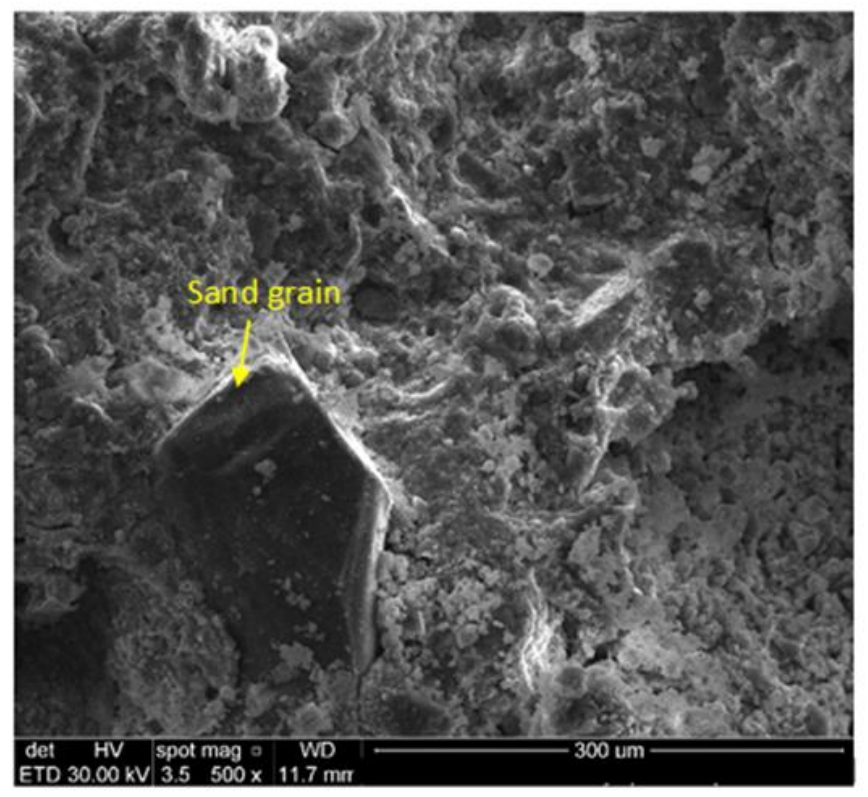

a

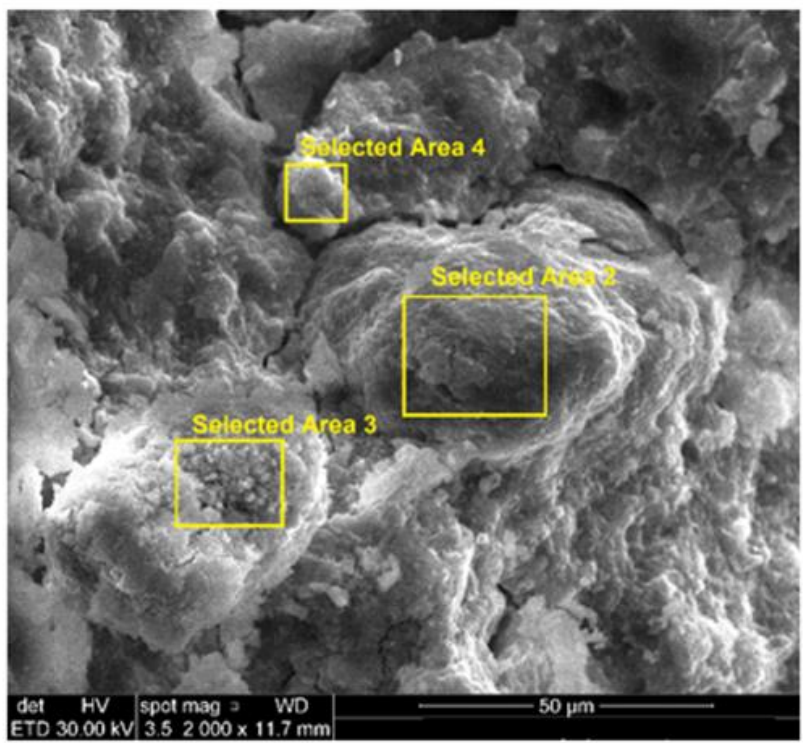

C

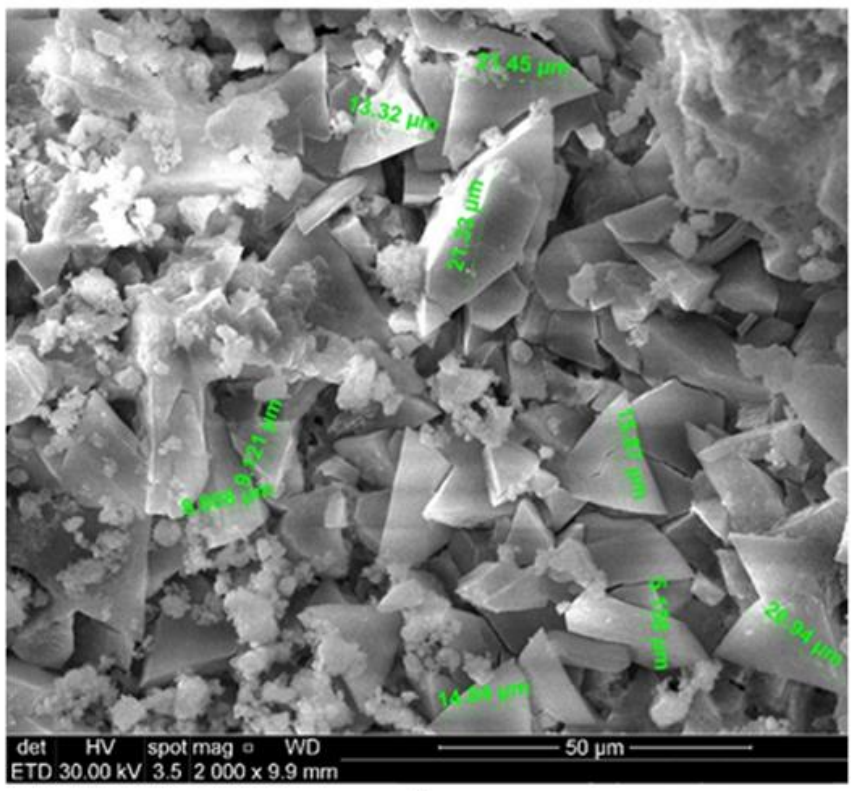

$\mathrm{b}$

\begin{tabular}{|c|c|c|c|}
\hline Element & $\begin{array}{c}\text { Area 2 } \\
\text { atomic } \\
\%\end{array}$ & $\begin{array}{c}\text { Area 3 } \\
\text { atomic } \\
\%\end{array}$ & $\begin{array}{c}\text { Area 4 } \\
\text { atomic } \\
\%\end{array}$ \\
\hline $\mathrm{Mg}$ & 10.25 & 4.32 & 11.25 \\
\hline $\mathrm{Al}$ & 2.26 & - & - \\
\hline $\mathrm{Si}$ & 3.47 & 0.78 & 0.84 \\
\hline $\mathrm{P}$ & 2.51 & 3.07 & 7.65 \\
\hline $\mathrm{K}$ & 4.04 & 2.63 & 5.88 \\
\hline $\mathrm{Ca}$ & 5.68 & 11.49 & 8.92 \\
\hline $\mathrm{Cr}$ & 1.04 & - & 0.1 \\
\hline $\mathrm{Fe}$ & 2.48 & 0.15 & 0.22 \\
\hline $\mathrm{C}$ & 0.02 & 3.85 & 1.54 \\
\hline $\mathrm{O}$ & 68.25 & 73.71 & 63.6 \\
\hline
\end{tabular}

Figure 10. SEM images and EDX analyses of D12s_MKP_2_Cr0.5 paste, at different magnifications: $(\mathbf{a}) \times 500$; (b) $\times 2000$; (c) $\times 2000$. 
The EDX analysis performed in three areas on SEM image presented in Figure 10c shows the presence of $\mathrm{Cr}, \mathrm{Al}$, and $\mathrm{Fe}$ (from waste [21]) mainly in area 2, which suggests the presence of a waste grain embedded in a layer (matrix) with $\mathrm{Ca}, \mathrm{K}$, and $\mathrm{P}$ content.

To assess the efficiency of the studied MPC and CMPC to immobilize $\mathrm{Cr}$, a leaching test (described in SR EN 12457-4: 2003 [23]) was performed for phosphate cement pastes hardened for 28 days. The results are presented in Figure 11.

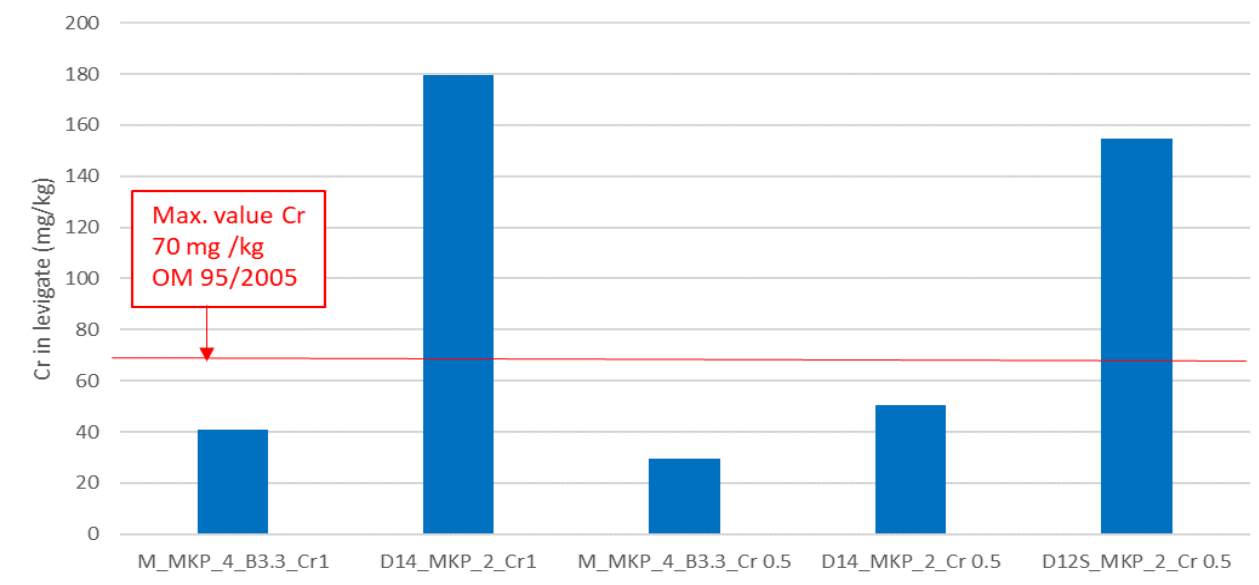

Figure 11. Cr content in levigates.

In Figure 11, one can observe that the MPCs based on calcined magnesite are effective for the immobilization of chromium even for a high waste content (M_MKP_4_B3.3_Cr1); the $\mathrm{Cr}$ content determined in leachate is below the limit stipulated by the Romanian Ministerial Order OM 95/2009 [31] for both phosphate cement pastes based on calcined magnesite.

The good immobilization of $\mathrm{Cr}$ in the MPCs based on calcined magnesite (M) can be explained by the presence of $\mathrm{K}$-struvite, which could play an important role $[16,32]$. Rouff [32] reported Cr adsorption or/and substitution in the struvite $\left(\mathrm{NH}_{4} \cdot \mathrm{H}_{2} \mathrm{PO}_{4} \cdot 6 \mathrm{H}_{2} \mathrm{O}\right)$, which precipitates from concentrate solutions of $\mathrm{MgCl}_{2} \cdot 6 \mathrm{H}_{2} \mathrm{O}$ and $\left(\mathrm{NH}_{4}\right)_{2} \mathrm{HPO}_{4}$, with $\mathrm{Cr}\left(\mathrm{NO}_{3}\right)_{3} \cdot 9 \mathrm{H}_{2} \mathrm{O}$ or $\mathrm{Na}_{2} \mathrm{CrO}_{4}$ additions.

For the phosphate cements based on calcined dolomite, only the one based on dolomite calcined at $1400{ }^{\circ} \mathrm{C}$ with a waste content corresponding to $0.5 \mathrm{wt} \% \mathrm{Cr}\left(\mathrm{D}_{14}\right.$-MKP_2_Cr0.5) fulfills the legal requirement. The reduced efficiency in immobilization of $\mathrm{Cr}$ in this type of cement can be due to the inhibition of K-struvite formation (suggested by XRD dataFigure 6). Nevertheless, the presence of hydroxyapatite (HAp) in this composition could contribute to the immobilization of $\mathrm{Cr}[33,34]$, explaining the low amount of chromium levigated in the CMPC with a lower chromium waste content (0.5 wt. \%).

The high Cr content assessed in the levigate of the CMPC based on $\mathrm{D}_{12 S}$ can be due to a low amount of K-struvite formed in this cement, due to partial substitution of dolomite with quartz sand.

\section{Conclusions}

In this study, we obtained and studied the properties of magnesium phosphate and calcium magnesium phosphate cements based on calcined magnesite and calcined dolomite (at different temperatures) with/without sand addition and potassium dihydrogen phosphate. The following conclusions can be drawn:

- The thermal treatment of dolomite at $1200^{\circ} \mathrm{C}$ and $1400{ }^{\circ} \mathrm{C}$ leads to the decomposition of calcium magnesium carbonate into $\mathrm{CaO}$ and $\mathrm{MgO}$. The increase in calcination temperature, from 1200 to $1400{ }^{\circ} \mathrm{C}$ reduces the reactivity of calcium and magnesium oxides vs. water or phosphate (MKP) solution; for the phosphate cements based on dolomite calcined at $1200^{\circ} \mathrm{C}$, an important increase in paste temperature during the setting and paste's expansion was noticed due to the high reactivity of oxides $(\mathrm{CaO}$ and $\mathrm{MgO}$ ); the increase of thermal treatment temperature at $1400{ }^{\circ} \mathrm{C}$ determines a 
decrease of the oxides' reactivity, and for a higher $\mathrm{KH}_{2} \mathrm{PO}_{4}$ dosage (corresponding to $\mathrm{D}_{14} / \mathrm{KH}_{2} \mathrm{PO}_{4}=2$ weight ratio), the pastes have measurable compressive strength at early ages. Nevertheless, for all specimens based on dolomite calcined at $1400{ }^{\circ} \mathrm{C}$, the compressive strengths dramatically decrease after 7 days of hardening, which is most probably due to a delayed hydration of $\mathrm{CaO}$ and $\mathrm{MgO}$.

- The main compounds observed in hardened phosphate binders based on calcined dolomite were calcium and magnesium hydroxides; in the case of specimens with a lower dosage of MKP (corresponding to $\mathrm{D}_{14} / \mathrm{MKP}=4$ weight ratio)—along with $\mathrm{Ca}(\mathrm{OH})_{2}$ and $\mathrm{Mg}(\mathrm{OH})_{2}$, a new compound was detected by XRD—hydroxyapatite (HAp); HAp results from the reaction of calcium with phosphate, which is brought into the system by MKP. For a higher dosage of MKP (corresponding to $\mathrm{D}_{14} / \mathrm{MKP}=2$ weight ratio) on the XRD patterns, peaks specific for the K-struvite $\left(\mathrm{KMgPO}_{4} \cdot 6 \mathrm{H}_{2} \mathrm{O}\right) \mathrm{com}$ pound are also present.

- In order to obtain a solid precursor for CMPC synthesis by the calcination of dolomite at relatively low temperature, a mixture of dolomite and quartz sand was thermally treated at $1200^{\circ} \mathrm{C}$ for $1 \mathrm{~h}$. The compressive strengths of resulting CMPC are lower in comparison with those assessed on phosphate cement based on calcined magnesite; however, they steadily increase up to 28 days. The lower values of compressive strengths assessed on these compositions are mainly due to the lower content of $\mathrm{MgO}$ available in this type of calcined dolomite $\left(\mathrm{D}_{12 \mathrm{~S}}\right)$ for the formation of K-struvite.

- The partial substitution of calcined magnesite and calcined dolomite with an industrial waste product with chromium content (corresponding to a Cr dosage of $0.5 \mathrm{wt} \%$ and $1 \mathrm{wt} \%$ ) led to a significant decrease of compressive strength. In the case of MPC based on calcined magnesite, this decrease can be explained by the reduction of $\mathrm{K}$-struvite amount due to the replacement of calcined magnesite and $\mathrm{KH}_{2} \mathrm{PO}_{4}$ with chromium waste, as well as by the increase of the water-to-solid ratio (necessary to obtain an adequate workability). For the CMPC based on dolomite calcined at $1400{ }^{\circ} \mathrm{C}\left(\mathrm{D}_{14}\right)$, the replacement of active components $\left(\mathrm{D}_{14}\right.$ and $\left.\mathrm{KH}_{2} \mathrm{PO}_{4}\right)$ with chromium waste further inhibits the formation of $\mathrm{K}$-struvite, and the compressive strengths decrease with the increase of the waste content. In the case of CMPC based on $\mathrm{D}_{12 \mathrm{~S}}$, the lower compressive strengths assessed for specimen with chromium waste are also explained by the lower amount of $\mathrm{K}$-struvite formed in this system (due to the decrease of $\mathrm{MgO}$ available for the reaction with $\mathrm{KH}_{2} \mathrm{PO}_{4}$ ).

- Phosphate cements based on calcined magnesite with a waste content corresponding to 1 and $0.5 \mathrm{wt} \% \mathrm{Cr}$ can effectively reduce the $\mathrm{Cr}$ leaching for pastes cured for 28 days; in the case of phosphate cements based on calcined dolomite $\left(\mathrm{D}_{14}\right)$, it was found that for a waste dosage corresponding to $0.5 \mathrm{wt} \% \mathrm{Cr}$, after 28 days of curing, the concentration of leached $\mathrm{Cr}$ is below the limit value imposed by the legislation currently in force. Nevertheless, considering the evolution of mechanical strength vs. time for this phosphate cement, it seems necessary to extend the evaluation of leached chromium for longer curing times (over 28 days). Although the CMPCs based on $\mathrm{D}_{12 \mathrm{~S}}$ developed adequate compressive strengths even at longer hardening times (28 days), the amount of chromium leached exceeded the limit imposed by the current legislation most probably due to the decrease of K-struvite content. The chromium immobilization in this type of CMPC can be improved if the appropriate amount of $\mathrm{D}_{12 S}$ (or chromium waste) is selected.

Author Contributions: Conceptualization, C.A.V. and A.B.; Investigation, C.A.V., A.I.N.; G.V.; Methodology: C.A.V. and A.B.; Supervision, A.B. and G.V.; Writing-original draft, C.A.V. and A.B.; Writing-review and editing, A.B. and G.V. All authors have read and agreed to the published version of the manuscript.

Funding: Cristina Andreea Vijan acknowledges the financial support of the Operational Programme Human Capital of the Ministry of European Funds through the Financial Agreement 51668/09.07.2019, SMIS code 124705. 
Institutional Review Board Statement: Not applicable.

Informed Consent Statement: Not applicable.

Data Availability Statement: Not applicable.

Conflicts of Interest: The authors declare no conflict of interest.

\section{References}

1. Xu, B.; Ma, H.; Li, Z. Influence of magnesia-to-phosphate molar ratio on microstructures, mechanical properties and thermal conductivity of magnesium potassium phosphate cement paste with large water-to-solid ratio. Cem. Concr. Res. 2015, 68, 1-9. [CrossRef]

2. Liu, R.; Yang, Y.; Sun, S. Effect of M/P and Borax on the Hydration Properties of Magnesium Potassium Phosphate Cement Blended with Large Volume of Fly Ash. J. Wuhan Univ. Technol. Mater. Sci. Ed. 2018, 33, 1159-1167. [CrossRef]

3. Yue, L.; Bing, C. Factors that affect the properties of magnesium phosphate cement. Constr. Build. Mater. 2013, 47, 977-983.

4. Jiang, Z.; Zhang, L.; Geng, T.; Lai, Y.; Zheng, W.; Huang, M. Study on the Compressive Properties of Magnesium Phosphate Cement Mixing with Eco-Friendly Coir Fiber Considering Fiber Length. Material 2020, 13, 3194. [CrossRef]

5. European Commission. Report on Critical Raw Materials for EU. Available online: http:/ / ec.europa.eu/DocsRoom/documents/ 11911/attachments/1/translations/en/renditions/native (accessed on 23 May 2021).

6. Alvarado, E.; Torres-Martinez, L.M.; Fuentes, A.F.; Quintana, P. Preparation and characterization of MgO powders obtained from different magnesium salts and the mineral dolomite. Polyhedron 2000, 19, 2345-2351. [CrossRef]

7. Subagjo; Wulandari, W.; Adinata, P.M.; Fajrin, A. Thermal decomposition of dolomite under $\mathrm{CO}_{2}$-air atmosphere. In AIP Conference Proceedings, Proceedings of the 1st International Process Metallurgy Conference (IPMC 2016), Bandung, Indonesia, 10-11 November 2016; AIP publishing: Dresden, Germany, 2017; Volume 1805. [CrossRef]

8. Olszak-Humienik, M.; Jablonski, M. Thermal behavior of natural dolomite. J. Therm. Anal. Calorim. 2015, 119, 2239-2248. [CrossRef]

9. Wulandari, W.; Subagjo; Mursito, A.T.; Juanjaya, F.J.; Alwi, M.F. Performance of Dolomite Calcination in a Bench-Scale Rotary Kiln. In MATEC Web of Conferences, Proceedings of the The 24th Regional Symposium on Chemical Engineering (RSCE 2017), Semarang, Indonesia, 15-16 November 2017; EDP Science: Les Ulis, France, 2018; Volume 156, pp. 704-708.

10. Roques, H.; Nugroho-Jeudy, L.; Lebugle, A. Phosphorus removal from wastewater by half-burned dolomite. Wat. Res. 1991, 25, 959-965. [CrossRef]

11. Engler, P.; Santana, M.W.; Mittleman, M.L.; Balazs, D. Non isothermal, In situ XRD analysis of dolomite decomposition. Thermochim. Acta 1989, 140, 67-76. [CrossRef]

12. Mako, E. The effect of quartz content on the mechanical activation of dolomite. J. Eur. Ceram. Soc. 2007, 27, 535-540. [CrossRef]

13. Gunasekaran, S.; Anbalagan, G. Thermal decomposition of natural dolomite. Bull. Mater. Sci. 2007, 30, 339-344. [CrossRef]

14. Yu, J.; Qian, J.; Wang, F.; Qin, J.; Dai, X.; You, C.; Jia, X. Study of using dolomite ores as raw materials to produce magnesium phosphate cement. Constr. Build. Mater. 2020, 253, 119147. [CrossRef]

15. Singh, D.; Wagh, A.S.; Cunnane, J.C.; Mayberry, J.L. Chemically bonded phosphate ceramics for low-level mixed-waste stabilization. J. Environ. Sci. Health 1997, 32, 527-541. [CrossRef]

16. Deng, Q.; Lai, Z.; Yan, T.; Wu, J.; Liu, M.; Lu, Z.; Lv, S. Effect of Cr (III) on hydration, microstructure of magnesium phosphate cement, and leaching toxicity evaluation. Environ. Sci. Pollut. Res. 2021, 28, 15290-15304. [CrossRef]

17. Wang, Y.S.; Dai, J.G.; Wang, L.; Tsang, D.C.W.; Poon, C.S. Influence of lead on stabilization/solidification by ordinary Portland cement and magnesium phosphate cement. Chemosphere 2018, 190, 90-96. [CrossRef] [PubMed]

18. Sua, Y.; Yanga, J.; Liuc, D.; Zhena, S.; Lind, N.; Zhoue, Y. Effects of municipal solid waste incineration fly ash on solidification/ stabilization of $\mathrm{Cd}$ and $\mathrm{Pb}$ by magnesium potassium phosphate cement. J. Environ. Chem. Eng. 2016, 4, 259-265. [CrossRef]

19. Vijan, C.A.; Badanoiu, A.; Nicoara, A.I.; Barcan, I. Effect of lead and nickel on the hardening processes and properties of phosphate cements. Rev. Rom. Mater. 2020, 50, 510-520.

20. ATSDR, Agency for Toxic Substances and Disease Registry. Available online: https://www.atsdr.cdc.gov/csem/chromium/ signs_and_symptoms.html (accessed on 29 June 2021).

21. Oproiu, C.; Parvan, M.; Voicu, G.; Badanoiu, A.I. Inertization of an industrial waste rich in chromium in composite portland cements. Rev. Rom. Mater. 2018, 48, 458-466.

22. SR EN 459-2. 2001-Building Lime. Part 2. Test Methods; ASRO: Bucharest, Romania, 2001.

23. SR EN 12457-4:2003. Characterization of Waste_Leaching_Compliance Test for Leaching of Granular Waste Materials and Sludges—Part 4: One Stage Batch Test at a Liquid to Solid Ratio of $10 \mathrm{l} / \mathrm{kg}$ for Materials with Particle Size Below $10 \mathrm{~mm}$ (without or with Size Reduction); ASRO: Bucharest, Romania, 2003.

24. Teoreanu, I. The Basics of Inorganic Binder Technology (in Romanian); Editura Didactică și Pedagogică: Bucharest, Romania, 1993.

25. Schorcht, F.; Kourti, I.; Scalet, B.M.; Roudier, S.; Sancho, L.D. Best Available Techniques (BAT) Reference Document for the Production of Cement, Lime and Magnesium Oxide (Integrated Pollution Prevention and Control). Available online: https:/ / ec.europa.eu/jrc/en/publication/reference-reports/best-available-techniques-bat-reference-document-productioncement-lime-and-magnesium-oxide (accessed on 23 May 2021). 
26. Stork, M.; Meindetsma, W.; Overgaag, M.; Neelis, M. A Competitive and Efficient Lime Industry. Cornerstone for a Sustainable Europe; Technical Report; Ecofys by order of EuLA: Brussels, Belgium, 2014; pp. 1-60.

27. Hashimoto, H.; Komaki, E.; Hayashi, F.; Uematsu, T. Partial Decomposition of Dolomite in CO 2 . J. Solid State Chem. 1980, 33, 181-188. [CrossRef]

28. Wells, L.S.; Taylor, K. Hydration of magnesia in dolomitic hydrated limes and putties. J. Res. Natl. Bur. Stand. 1937, 19, 215-236. [CrossRef]

29. Wagn, A.S. Chemically Bonded Phosphate Ceramics; Elsevier: Amsterdam, The Netherlands, 2016.

30. Vijan, C.A.; Badanoiu, A. The influence of potassium phosphate and fly ash addition on the setting time and mechanical strengths of magnesium phosphate cement. Univ. Politeh. Buchar. Sci. Bull. Ser. B 2020, 82, 21-32.

31. Romanian Ministerial Order no. 95/2005 on the Establishment of Acceptance Criteria and Preliminary Acceptance Procedures for Landfill Waste and the National List of Waste Accepted in Each Landfill Class (According to 2003/33/EC). Available online: https: / /www.ecotic.ro/wp-content/uploads/2015/07/1e62400fcaa487767564187df6343e669b6f36ad.pdf (accessed on 23 May 2021).

32. Rouff, A.A. The use of TG/DSC-FT-IR to assess the effect of Cr sorption on struvite stability and composition. J. Therm. Anal. Calorim. 2012, 110, 1217-1223. [CrossRef]

33. Nayak, A.; Bhushan, B. Hydroxyapatite as an advanced adsorbent for removal of heavy metal ions from water: Focus on its applications and limitations. Mater. Today Proc. 2021. [CrossRef]

34. Campisi, S.; Evangelisti, C.; Postole, G.; Gervasini, A. Combination of Interfacial Reduction of Hexavalent Chromium and Trivalent Chromium Immobilization on Tin-Functionalized Hydroxyapatite Material. Appl. Surf. Sci. 2021, 539, 148227. [CrossRef] 